This is the version of the article accepted for publication in Global Public Health published by Taylor \& Francis and available online 14 Feb 2017 at: http://dx.doi.org/10.1080/17441692.2017.1289230

Accepted version downloaded from SOAS Research Online: https://eprints.soas.ac.uk/23603/

\title{
'Gendercide’, Abortion Policy, and the Disciplining of Prenatal Sex-Selection in Neoliberal Europe
}

Navtej Purewal, SOAS University of London

Lisa Eklund, University of Lund

\begin{abstract}
This article examines the contours of how sex-selective abortion (SSA) and 'gendercide' have been problematically combined within contemporary debates on abortion in Europe. Analysing the development of policies on the topic, we identify three 'turns' which have become integral to the biopolitics of SSA in Europe: the biomedical turn, the 'gendercide' turn, and the Asian demographic turn. Recent attempts to discipline SSA in the UK and Sweden are examined as a means of showing how the neoliberal state in Europe is becoming increasingly open to manoeuvres to undermine the right to abortion, even where firm laws exist.
\end{abstract}

Keywords: Biopolitics, gendercide, sex selection, abortion, neoliberal state

\section{Introduction}

Sex-selective abortion (SSA) and 'gendercide' have been problematically combined with reignited controversies in contemporary debates on abortion in Europe. The notion of 'missing girls' (Sen, 2003) implicit in the term 'gendercide' highlights the fact that girls are being systematically discriminated against before birth and even at conception. While legal statute in most European countries recognises the right to abortion, ${ }^{1}$ the European Parliament and other bodies, such as the Human Fertility and Embryology Authority (HFEA) in the UK, have recently reviewed existing policies in light of the availability of reproductive technologies to sex-select and, in particular, in 
This is the version of the article accepted for publication in Global Public Health published by Taylor \& Francis and available online 14 Feb 2017 at: http://dx.doi.org/10.1080/17441692.2017.1289230

Accepted version downloaded from SOAS Research Online: https://eprints.soas.ac.uk/23603/

response to daughter de-selection.

At the root of European legislation has been the idea that the 'right to choice' and access to technologies may encourage people with cultural biases against females to sex-select for social, not medical, reasons. Further, the widely acknowledged skewed sex ratios against females, particularly at birth, have also highlighted 'missing women’ in the demographic data of some countries (most notably in Asia) as a result of the systematic intervention of reproductive technologies. Hence, the term 'gendercide' began to be incorporated into both reproductive health-related policy and anti-abortion campaigning, and SSA became a concern for policy makers at both national and European levels. This article sheds light on the problematic uses of 'gendercide' in contemporary abortion discourse and debate. We argue that 'gendercide' as a concept has been co-opted by not only the anti-abortion movement but also by populist and conservative political forces attempting to gain political mileage. The Asian examples of India and China, in particular, have been used in order to transpose an argument against abortion as a 'choice', particularly in contexts where diasporic communities from those countries are branded as 'deviant aborters' (Purewal, 2010). However, as is the case of Sweden where ethnicity is not highlighted in abortion-related statistics, SSA poses even more elusive questions to existing abortion law. By arguing that 'deviant aborters’ warrant a change to broader existing abortion laws, the criminalisation of SSA has come to sit centrally within the questions around the right to abortion, threatening to reverse the achievements of the abortion rights movement since the 1960s.

This article approaches policy-making on SSA as a process of institutional change. Drawing theoretically and analytically on the work of Daniel Béland (2007) 
This is the version of the article accepted for publication in Global Public Health published by Taylor \& Francis and available online 14 Feb 2017 at: http://dx.doi.org/10.1080/17441692.2017.1289230

Accepted version downloaded from SOAS Research Online: https://eprints.soas.ac.uk/23603/

this article regards systematic analysis of ideational processes as key to understanding not only how institutional change takes place, but also in what direction. Paying attention to ideas and how they evolve over time is closely related to the stance that institutional change typically is an incremental process, where change happens slowly (Hall, 1993; Thelen, 2004). Moreover, Kathleen Thelen (2004) argues that major disruptions and critical junctures are often preceded by incremental change, which needs to be studied in more detail in order to understand institutional change. Thelen identified two mechanisms of incremental change — conversion and layering — both of which are examined in this article in the context of abortion policy. According to her, layering involves 'the grafting of new elements onto an otherwise stable institutional framework. Such amendments can alter the overall trajectory of an institution's development' (Thelen, 2004, p. 35). Through conversion institutions evolve 'as the adoption of new goals or the incorporation of new groups into the coalitions on which institutions are founded can drive a change in functions these institutions serve or the role they perform' (Thelen, 2004, p. 36). The aim of the article is twofold. First, it aims at illuminating how conversion of goals and actors concerned with SSA has evolved over time, with special emphasis on ideational processes. Second, it aims to further a more nuanced understanding of how disciplining SSA is becoming grafted onto abortion policy in Sweden and the UK.

\section{The neoliberal state, 'gendercide' and disciplining abortion}

Focusing on ideational processes of institutional change is particularly relevant to the neoliberal state, marked by multiple layers of governance in which political parties, interest groups, experts, market actors, and the media are all important actors. The 
This is the version of the article accepted for publication in Global Public Health published by Taylor \& Francis and available online 14 Feb 2017 at: http://dx.doi.org/10.1080/17441692.2017.1289230

Accepted version downloaded from SOAS Research Online: https://eprints.soas.ac.uk/23603/

neoliberal state, in its multiple shades and convergences of capital and political power, performs a function of discipline in order to 'improve the exercise of power by making it lighter, more rapid, more effective, a design of subtle coercion for a society to come’ (Foucault, 1977, p.71). As Loïc Wacquant (2009) argues, the accentuation of the punitive side of the state, rather than being a response to crime, is in fact a reaction to social insecurity. He further goes on to highlight how European states have, like the United States, begun to hype the idea of 'insecurity' as closely linked to poverty, unemployment, economic disparity, and marginalisation. Most importantly, he characterises the Western European model of penalisation as one which meshes the 'iron fist' of the penal state with the 'invisible hand' of the market (Wacquant, 2011). There are, of course, variations across Europe. In Scandinavian social democracies the state plays a distinctive role in shaping public health as a model of equity, although a recent surge in privatisation has taken place. The UK's decline in welfare provision shows how public health concerns are subject to trends which undermine entitlements to services which are presented as being limited, finite, and under threat.

The prenatal de-selection of girls is a great challenge to the neoliberal state, which wants to limit its role, while at the same time sees biopolitics and a 'healthy population' as core objectives. The elimination of women and girls due to the sheer fact that they are female has been named differently over the course of history. Diana E. H. Russell terms the practice 'femicide' which, according to her, involves 'the killing of females by males because they are females' (cited in Torres-Coronas, Belzunegui-Eraso, and Moreno-Gené, 2015, p. 309). Others have used the term to refer to acts of killing women due to misogynous and sexist worldviews, implying that the act of killing does not have to be carried out by a male. Mary Anne Warren (1985) coined the term 'gendercide', which is a wider concept, including the killing of 
This is the version of the article accepted for publication in Global Public Health published by Taylor \& Francis and available online 14 Feb 2017 at: http://dx.doi.org/10.1080/17441692.2017.1289230

Accepted version downloaded from SOAS Research Online: https://eprints.soas.ac.uk/23603/

both women and men on the base of their sex/gender. While Russell was concerned with the killing of living human beings, Warren also discussed SSA, although she acknowledged that not all SSA is based on sexist views, such as parents wanting a balance between daughters and sons (Warren, 1985). Warren later altered her standpoint and argued for SSA to be ethically defensible only where no gender preference existed (Warren, 1999, cited in Nie 2010), a stance which has been critiqued for differentiating reproductive rights of women in the West from women in the Global South (Macklin, 1999).

Our concerns in this article are with how SSA has been handled by different states in Europe, using the tools and language of criminalisation as a means of exerting an emerging era of neoliberal biopolitics. While the 'discipline mechanism' of criminalised abortion reserves the more severe end of the spectrum for raising spectacles, such as sting operations of clinics or medical professionals performing SSA, the remainder of the spectrum has a symbolic function in creating a coercive environment of fear from public exposure or shaming, rather than fear of actual punishment. Thus, abortion and fear of the law come to be part of a wider biopolitics in which populations are shaped according to the political agendas governing them (Foucault, 2009). Despite SSA being an elusive and often unidentifiable practice (Hesketh, 2011; Menon, 1995), its entry into the domain of criminalisation shows how it becomes linked to other issues such as, for example, the impediment of reproductive autonomy of racialised or marginalised communities (Roberts, 1997), population control (Eklund and Purewal 2017; Ginsburg and Rapp, 1995), and stateendorsed religious dictate against abortion (Smyth, 2005). 
This is the version of the article accepted for publication in Global Public Health published by Taylor \& Francis and available online 14 Feb 2017 at: http://dx.doi.org/10.1080/17441692.2017.1289230

Accepted version downloaded from SOAS Research Online: https://eprints.soas.ac.uk/23603/

\section{Methods and selection of cases}

The analysis presented in this study is based on secondary literature on SSA and prenatal sex-selection, as well as policy documents at the European level.

Furthermore, two European country cases have been selected—Sweden and the UKas they represent national-level examples of where the practice of SSA has been widely debated in the media and in policy circles. Both countries have internal political actors that have highlighted SSA (e.g. the 'Christian right', conservative forces, anti-immigration lobbyists), and each has been put under scrutiny by the wider European community for their 'generous' abortion laws (see e.g. CoE, 2015).

Legislative wording and media-generated cases showing physicians' knowing or unknowing role in supporting SSA have contributed to the moral panic which has surrounded Europe's concerns around the practice. Our two country cases of Sweden and the $\mathrm{UK}^{2}$ represent different articulations of this.

\section{Sex-selective abortion policy in Europe}

Although SSA has been subject to global policy discussion through several United Nations (UN) organisations and international conferences since the mid-1990s, policy initiatives at the European level are more recent, and have developed in parallel in two intergovernmental organisations; the Council of Europe (CoE), consisting of 47 European States, and the European Union (EU), consisting of 28 European states. Sweden and the $\mathrm{UK}^{3}$ are members of both organisations. Analysing the ideational underpinnings of policy documents on the topic of sex selection in Europe, we identify three 'turns' which have become integral to the biopolitics of SSA; (1) the biomedical turn, (2) the 'gendercide' turn, and (3) the Asian demographic turn. At the European level, these turns represent ideational processes which have contributed to 
This is the version of the article accepted for publication in Global Public Health published by Taylor \& Francis and available online 14 Feb 2017 at: http://dx.doi.org/10.1080/17441692.2017.1289230

Accepted version downloaded from SOAS Research Online: https://eprints.soas.ac.uk/23603/

policy conversion, where new groups have been incorporated into coalitions on which abortion policies are founded, and where the goal of abortion policy has become narrowed down to impede the unconditional right to abortion.

\section{The biomedical turn}

Prenatal sex-selection up until the late 1990s had been viewed as a matter of access to abortion rather than access to biomedical reproductive technologies. The advent of pre-selective technologies reflected a turn from abortion as a medical procedure, to sex selection as a set of pre-conception biomedical technologies. The biomedical turn during this time began to make distinctions between methods of primary sex-selection (before fertilisation) including sperm sorting and the separation of $\mathrm{X}$ and $\mathrm{Y}$ chromosomes in order to increase the likelihood of the desired sex; and secondary sex-selection (after fertilisation) where in vitro fertilised (IVF) embryos of only the required sex are placed in the womb. The increasing ambiguity between biomedical possibilities to sex-select, and the regulation of access to such technologies, began to shape policy discourse in Europe beginning with the 1997 Convention for the Protection of Human Rights and Dignity of the Human Being with regard to the Application of Biology and Medicine: Convention on Human Rights and Biomedicine (CoE, 1997). ${ }^{4}$ The biomedical turn did not present a layering of the institutional framework surrounding abortion as it concerned medically-assisted procreation; but it did indirectly contribute to conversion, in the sense that it made explicit that selecting the sex of a child was not allowed except for on medical grounds.

\section{The 'Gendercide' and the Violence against Women (VAW) turn}

At several international conferences in the 1990s, such as the Beijing Platform for 
This is the version of the article accepted for publication in Global Public Health published by Taylor \& Francis and available online 14 Feb 2017 at: http://dx.doi.org/10.1080/17441692.2017.1289230

Accepted version downloaded from SOAS Research Online: https://eprints.soas.ac.uk/23603/

Action in 1993, and the International Conference on Population and Development (ICPD) in 1994, a wide range of new state and non-state actors began to frame SSA as a matter of violence against women (VAW). In April 2002, the Committee of Ministers on the Protection of Women against Violence recommended that member states of the Council of Europe should: 'prohibit enforced sterilisation or abortion, contraception imposed by coercion or force, and pre-natal selection by sex, and take all necessary measures to this end' (CoE, 2002, item 79). By bringing pre-natal selection by sex under recommendations concerning VAW, hence acknowledging the human rights of the foetus, the Council of Europe opened up space for sex selection to be conceptualised as a matter of VAW and for SSA to be represented as 'killing', as is implied in the terms 'femicide' and 'gendercide'.

In May 2010, a group of 22 members of the Parliamentary Assembly of the Council of Europe drafted a motion for a resolution pushing for the regulation of SSA; Sex-selective Abortion - 'Gendercide’ (CoE, 2010), tabled by Mr Luca Volontè (Italy). Signatories of the motion represented 11 countries of the Council of Europe (Austria, Bulgaria, Estonia, Ireland, Italy, Lichtenstein, Lithuania, Moldova, Serbia, Spain, and the UK). All signatories were men except three (from Italy, Serbia, and Spain). The 22 signatories further represented all five political groups of the Assembly; the Socialist Group (SOC), the Group of the European People’s Party (EPP/CD), the Liberal, Democratic and Reformers' Group (LDR), the European Democratic Group (EDG), and the Group of the Unified European Left (UEL). The overwhelming majority (16 out of 22) were part of the EPP/CD, consisting of Christian-democratic parties, conservative parties, and parties with other centre-right political perspectives. The motion notes that SSA has 'aptly been termed 'gendercide' by some observers' and it also refers to SSA as ‘pre-natal killing'. It further attributes 
This is the version of the article accepted for publication in Global Public Health published by Taylor \& Francis and available online 14 Feb 2017 at: http://dx.doi.org/10.1080/17441692.2017.1289230

Accepted version downloaded from SOAS Research Online: https://eprints.soas.ac.uk/23603/

a number of issues threatening global security to SSA, such as 'large numbers of young males without any prospect of being able to find wives and founding families creates a dangerous potential of social unrest, violence and political radicalization’ (CoE, 2010). Interestingly, it also makes reference to concerns over declining birth rates, as the 'pre-natal killing of females will in the near future lead to a further radical decline of birth rates’ (CoE, 2010). This echoes previous concerns over fertility rates as motivation for regulating abortion rights, for example in Romania (Keil and Andreescu, 1999). The motion further invites the member states of the Council of Europe to ‘condemn sex-selective abortion'.

Following the motion for a resolution on Sex-selective Abortion - 'Gendercide', the Committee on Equal Opportunities for Women and Men of the Council of Europe issued the report Prenatal sex-selection, dated 16 September 2011 (CoE, 2011a). The rapporteur, Ms Doris Stump (Switzerland), represented the Socialist Group. Importantly, the rapporteur addressed the term 'gendercide' in her report, and argued for the more neutral term 'prenatal sex-selection', which also encompasses preconception sex-selection:

I would like to use a terminology which is neutral as regards the nature of the embryo/foetus and the question of its right to life. ... I have proposed to modify the title of the report to 'Prenatal sex-selection', so as to address prenatal sexselection irrespective of how it is carried out, as I will not only address abortion but also preimplantation genetic diagnosis (PDG) and other potential methods of sex-selection. (CoE, 2011a, p. 9)

The rapporteur also rejected the conceptualisation of SSA as an act of VAW, partly refuting the recommendations by the Committee of Ministers (CoE, 2002) on the protection of women against violence: 
This is the version of the article accepted for publication in Global Public Health published by Taylor \& Francis and available online 14 Feb 2017 at: http://dx.doi.org/10.1080/17441692.2017.1289230

Accepted version downloaded from SOAS Research Online: https://eprints.soas.ac.uk/23603/

In line with the neutrality approach explained above, I will refrain from defining prenatal sex-selection as a form of violence against women as such, because such a definition would imply that the female foetus is a woman. (CoE, 2011a, p. 9)

A fortnight later on 3 October 2011, the Parliamentary Assembly of the Council of Europe adopted Resolution 1829 on Prenatal sex-selection (CoE, 2011b). Different from the motion that preceded it, the resolution does not make reference to gendercide, nor does it refer to SSA as 'killing'. Rather, the resolution states that:

The Parliamentary Assembly condemns the practice of prenatal sex-selection as a phenomenon which finds its roots in a culture of gender inequality and reinforces a climate of violence against women, contrary to the values upheld by the Council of Europe. (CoE, 2011b, para. 4)

The resolution further calls on 'the member states to collect data on sex-selection in the context of the use of all techniques of medically assisted procreation' (CoE, 2011b, para. 8.3), also echoing the bio-medical turn. It further calls on the member states to prohibit SSA by introducing 'legislation with a view to prohibiting sexselection in the context of assisted reproduction technologies and legal abortion, except when it is justified to avoid a serious hereditary disease' (CoE, 2011b, para. 8.7).

Despite the reservation of framing prenatal sex-selection as a VAW issue (CoE, 2011a), Recommendation 1979 which followed Resolution 1829 states that '[p]renatal sex-selection ... touches upon core activities of the Council of Europe such as ... the prevention of and fight against gender-based violence' (CoE, 2011c, §2) and the Assembly invites the Committee of Ministers to 'bring to the attention ... the issue of prenatal sex-selection and its underlying causes, in light of its links with violence against women’ (CoE, 2011c, para. 3.1). 
This is the version of the article accepted for publication in Global Public Health published by Taylor \& Francis and available online 14 Feb 2017 at: http://dx.doi.org/10.1080/17441692.2017.1289230

Accepted version downloaded from SOAS Research Online: https://eprints.soas.ac.uk/23603/

The resistance to framing SSA as a matter of VAW was also lost in the European Parliament, which adopted a resolution of 16 December 2010 on the Annual Report on Human Rights in the World 2009 and the European Union's policy on the matter (EU, 2010) wherein it framed SSA as an issue of human rights and VAW. The Report:

insists that women’s rights be explicitly addressed in all human rights dialogues, and in particular the combating and elimination of all forms of discrimination and violence against women and girls, including, most prominently, genderselected abortion. (EU, 2010, para. 76)

By framing SSA as a matter of VAW, despite resistance to doing so, the European policy framework that evolved in the early $21^{\text {st }}$ century effectively subscribed to a view where the foetus was considered to have human rights, a view consistent with the anti-abortion movement, showing clear signs of conversion of both abortion policy goals at the European level, and the emergence of new actors with a stake in abortion policy, including the European Parliament, the Council of Europe, and national and Europe-wide political parties.

\section{The Asian demographic turn and the reification of 'gendercide'}

Although the Council of Europe’s 2010 motion Sex-selective Abortion - 'Gendercide' had made reference to the worrisome demographic developments in South and East Asia, where sex ratio at birth (SRB) has been skewed in favour of boys for decades, the term 'gendercide' was not part of the resolution which followed (CoE, 2011b), as discussed above. However, the significance of sex-selection in Asia as a cause for concern took hold within the EU, suggesting that a moral panic had been triggered due to the demographics of China and India in particular, although some European 
This is the version of the article accepted for publication in Global Public Health published by Taylor \& Francis and available online 14 Feb 2017 at: http://dx.doi.org/10.1080/17441692.2017.1289230

Accepted version downloaded from SOAS Research Online: https://eprints.soas.ac.uk/23603/

countries also began to report skewed SRB in favour of boys. Figure 1 below illustrates SRB in selected European countries.

\section{FIGURE 1}

As evident from Figure 1, Albania, Armenia, and Azerbaijan (non-EU countries), all have high SRB, although it fell between 2000 and 2012 in the two latter countries. Figure 1 also indicates that between 1962 and 2012, the EU average remains at just under 106, which is considered to be within the normal range of 103-107. The UK remained steady at around 105, while Sweden hovered around 106 over the same period of time.

Despite lack of evidence from the EU context, ideationally the peril of SSA took hold among members of the European parliament. In June 2013, the Committee on Women's Rights and Gender Equality of the European Union issued the report Gendercide: The missing women? (EU, 2013a), wherein it drew heavily on the situation of missing women in Asia. A resolution with the same name was later adopted by the European Parliament on 8 October 2013 (EU, 2013b), stating:

\footnotetext{
'gendercide' ... take[s] the forms of infanticide and violence through sexselection ... have been used to refer to the killing of women and girls as the utmost expression of discrimination and violence against women. (EU, 2013b, para. A)
}

Although the above statement does not explicitly make reference to prenatal sexselection, the following paragraph alludes to the understanding that SSA constitutes gendercide: 
This is the version of the article accepted for publication in Global Public Health published by Taylor \& Francis and available online 14 Feb 2017 at: http://dx.doi.org/10.1080/17441692.2017.1289230

Accepted version downloaded from SOAS Research Online: https://eprints.soas.ac.uk/23603/

gendercide is committed everywhere [where] pregnant women, on purpose or under pressure, decide not to give birth to girl foetuses because they are considered a burden to the society. (EU, 2013b, para. D)

The quote implies that the resolution regards SSA as an act of 'gendercide', and hence an act of killing. In order to address the problem of SSA, the resolution further calls on the Commission and the Member States to 'identify clinics in Europe that conduct sex-selective abortions, provide statistics on this practice and elaborate a list of best practices for preventing them' (EU, 2013b, para. 18). It further calls on the Commission and all relevant stakeholders to:

take the necessary legislative or other measures to ensure that practicing forced abortions and sex-selective surgery to terminate pregnancy without prior and informed consent or understanding of the procedure by the women involved is criminalised. (EU, 2013b, para. 34)

The resolution further makes reference to SSA as a human rights abuse:

... Union assistance should not be provided to any authority, organisation or programme which promotes, supports or participates in the management of any action which involves such human rights abuses as coercive abortion, forced sterilisation of women or men, or determination of foetal sex resulting in prenatal sex-selection or infanticide. (EU, 2013b, para. 41)

The statement above also opens up for EU member states to withhold funding for sexual and reproductive health and rights (SRHR) assistance if organisations are found to support SSA. Similarities can be found with The Helms Amendment to the Foreign Assistance Act, which was passed in 1973, prohibiting the use of US state funds for the performance of abortion 'as a method of family planning'.

Conceptualising SSA as gendercide poses important questions for the abortion rights movement, since arguing that aborting a foetus based on sex constitutes killing, while 
This is the version of the article accepted for publication in Global Public Health published by Taylor \& Francis and available online 14 Feb 2017 at: http://dx.doi.org/10.1080/17441692.2017.1289230

Accepted version downloaded from SOAS Research Online: https://eprints.soas.ac.uk/23603/

aborting a foetus for other reasons does not constitute killing, seems contradictory if not irreconcilable. Furthermore, as discussed further on in this article, focusing on SSA takes focus away from the biomedical concern over choosing the sex of the child through pre-implantation and pre-conception sex-selection, which is becoming increasingly available as a means to sex-select, at least for those who can afford it (Eklund and Purewal, 2017).

\section{5. 'Deviant Aborters' and the Serious Crime Bill in the UK}

Much dissonance surrounds the question of whether more restrictive laws are appropriate to address SSA. Following policy reviews by the Human Fertility and Embryology Authority (HFEA) in 1993, 2003, and 2007, all clinics that offer sperm processing in the UK are required to be licensed by the HFEA and can only offer sex selection for medical purposes. ${ }^{5}$ This distinction between medical as opposed to social reasons for sex selection, highlighted the significance of both the biomedical turn and the Asian demographic turn discourses in shaping abortion debates in the UK. In November 2014, Conservative UK Member of Parliament Fiona Bruce, Chair of the All Party Pro-Life/Anti-Abortion Group, introduced the Abortion (Sex Selection) Bill in the UK Parliament, which alleged that existing abortion law as stated in the 1967 Abortion Act was not sufficient in addressing the issue of sex selection. ${ }^{6}$ The proposals, purporting that clarity was needed in existing abortion legislation as a means of addressing sex selection, argued that abortions were being carried out by women and couples seeking to de-select females for cultural reasons. The Abortion (Sex-selection) Bill proposed to include new measures into Part 5 of the Government's Serious Crime Bill which would identify abortion as a crime when committed for social or cultural reasons, interpreting the existing law through the lens 
This is the version of the article accepted for publication in Global Public Health published by Taylor \& Francis and available online 14 Feb 2017 at: http://dx.doi.org/10.1080/17441692.2017.1289230

Accepted version downloaded from SOAS Research Online: https://eprints.soas.ac.uk/23603/

of 'gendercide'. ${ }^{7}$ This presented an attempt to layering to abortion policy by suggesting a restriction of the reasons deemed legitimate for seeking abortion. The medical reasons for abortion in section F1(d) (the fetal anomaly clause) were left out of the Serious Crime debate making the cultural and social reasons for abortion the focus of attention. In this light, the wording of existing abortion law in relation to sex-selection remained unchanged but sex-selective abortion as a social problem became institutionalised (Lee, 2017).

Plans to include the abortion amendment into the Serious Crime Bill sought to criminalise SSA on the basis of evidence that South Asian women (specifically Indiaborn women) showed a propensity to undergo sex-selective diagnostic and abortive procedures (Dubuc and Coleman, 2007). Based on annual data on live births for England and Wales from 1969 to 2005 taken from the Office for National Statistics (ONS), the findings of Dubuc and Coleman's (2007) study pointed to a four-point increase in the sex ratio at birth for children borne by mothers born in India with higher parity births, with no evidence of this trend amongst UK-born South Asian mothers (See Table 1).

\section{Table 1.}

Representing the discourses of both 'gendercide' and the Asian demographic turn, although before they were discernible at the European level of abortion policy making, Dubuc and Coleman reveal in their analysis:

Female-selective abortion raises issues of ethics and has led to the concern among the British medical services about disclosing the sex of the fetus at the time of the second routine pregnancy ultrasound scan (at 20 weeks of pregnancy). The apparent discrimination against female fetuses also calls into 
This is the version of the article accepted for publication in Global Public Health published by Taylor \& Francis and available online 14 Feb 2017 at: http://dx.doi.org/10.1080/17441692.2017.1289230

Accepted version downloaded from SOAS Research Online: https://eprints.soas.ac.uk/23603/

question the adherence of some India-born immigrants to the norms of a Western society. (Dubuc and Coleman, 2007, pp. 396-7; our emphasis)

Based on SRB data, the label of deviancy is applied to 'India-born migrants' in this statement, which also projects ‘the norms of a Western society’ as oppositional to those of (Indian) migrant communities, centring a normative and problematic notion of reproductive citizenship. It is also worth noting that the 'Asian demographic turn' was invoked in the UK context before it entered European-level policy documents, possibly suggesting that UK representatives in the European Parliament were instrumental in bringing about the Asian demographic turn at the European level.

The focus upon migrant women's reproductive behaviour at the centre of the parliamentary debate, highlighted another dimension to the disciplinary functions of the neoliberal state. ${ }^{8}$ Sting operations carried out by the Telegraph newspaper in 2012, in which undercover reporters went to clinics posing as women seeking SSA, resulted in undercover filming of three doctors who were investigated by police and the Crown Prosecution Service with no charges brought. However, this resulted in an 'uncovering' of the issue of SSA and led to a public enquiry. The Department of Health (DoH) which investigated the issue stated that 'when broken down by the mothers' country of birth, no group is statistically different from the range that we would expect to see naturally occurring' (DoH 2014). ${ }^{9}$ Rather, the UK average SRB of 105 males to every 100 females is also the average SRB for mothers of all birthplaces in the UK sample. The Department of Health further stated that $91 \%$ of all abortions in the UK take place before the sex of the foetus can be identified in any case, making the 'evidence’ for SSA appear even more speculative.

Alongside this 'evidence', the anti-abortion lobby group drew support from voluntary 
This is the version of the article accepted for publication in Global Public Health published by Taylor \& Francis and available online 14 Feb 2017 at: http://dx.doi.org/10.1080/17441692.2017.1289230

Accepted version downloaded from SOAS Research Online: https://eprints.soas.ac.uk/23603/

sector actors and faith organisations representing or engaging with South Asian communities to further its position, which further gave credence to the demographic patterns in India with the UK context. ${ }^{10}$ Hence, national abortion law in the UK was being challenged as being insufficient to address the reproductive behaviour of women from migrant backgrounds who, in the process, had become identified as ‘deviant aborters’ both from inside and outside of South Asian communities. The Serious Crime Bill, including other measures of criminalisation, such as Female Genital Mutilation (FGM) and other forms of VAW, became an issue for the British state to sharpen its disciplinary function without addressing broader issues of social welfare, support for vulnerable groups, or social equity, as we have argued elsewhere (Eklund and Purewal, 2017). Instead, women’s reproductive choice more broadly became subject to scrutiny by the anti-abortion lobby, for what it argued was an ambiguity within the 1967 abortion legislation which technically did not legalise abortions, but instead provided a legal defence for those carrying them out. ${ }^{11}$ In its first reading on 4 November 2014 as a 10 Minute Rule Bill, the amendment bill received 181 aye's to 1 nay. Though the bill to amend existing abortion law could have had a second reading, it was withdrawn by Fiona Bruce MP, and the issue was instead shifted to the Serious Crime Bill. This single issue, when framed as one of VAW and 'gendercide', attracted widespread support from positions, groups, and organisations otherwise divided across the political spectrum, suggesting a process of conversion of both actors and goals. The VAW agenda also became a means by which the British state could spread its tentacles into communities it wanted to control, as well as to highlight its attentiveness to social issues without making financial investment in social welfare.

However, abortion rights activists, feminists, and civil liberties groups began to 
This is the version of the article accepted for publication in Global Public Health published by Taylor \& Francis and available online 14 Feb 2017 at: http://dx.doi.org/10.1080/17441692.2017.1289230

Accepted version downloaded from SOAS Research Online: https://eprints.soas.ac.uk/23603/

recognise the Serious Crime Bill’s inclusion of the Abortion (Sex-selection) Act as a threat to reproductive rights more broadly. The discourse of 'gendercide', which had been the amendment’s central organising principle in proposing to discipline reproductive behaviour, became problematised although not entirely discredited as sex selection had in the process become institutionalised as a social problem (Lee, 2017). Thereafter, only a few months on from the first reading, 23 February 2015 the amendment bill was voted upon which saw a parliamentary rejection of the proposal to include abortion in the Serious Crime Bill, with 292 nays to 201 aye’s, a difference of 91 . The polarised representation of the abortion rights and anti-abortion positions had eventually been disrupted by the use of 'gendercide', which in the first vote on the bill had appealed to both sides of this traditional fault line.

The attempts to include SSA in the Serious Crime Bill exemplified how a public health issue could become quickly incorporated into a crime discourse as a means of furthering the neoliberal state's shrinking role in terms of service provision (for example, through pregnancy and post-natal support services), meanwhile heightening its penal role (Wacquant, 2011). Despite there being no significant evidence of sex-selection being practised, the 'gendercide' and Asian demographic turn discourses were freely utilised in the rhetoric of the Abortion (Sex-selection) Amendment Act. The discipline-blockade function of the state in 'arresting evil' (Foucault, 1977) marked out 'deviant' aborting women supposedly in need of protection from the reproductive choices to which existing abortion law entitled them. Meanwhile, the array of voices from across the abortion rights movement, as well as within the South Asian women's and other women's movements, highlighted how the state's closure of specialist services for women (and sharp reduction of state funding to South Asian women's organisations) had created a sense of agency and collective 
This is the version of the article accepted for publication in Global Public Health published by Taylor \& Francis and available online 14 Feb 2017 at: http://dx.doi.org/10.1080/17441692.2017.1289230

Accepted version downloaded from SOAS Research Online: https://eprints.soas.ac.uk/23603/

consciousness. These groups challenged the nature of the British state, not least in terms of cuts to social and public funding, but also by opposing the Bill. ${ }^{12}$ Petitions, public debates, and commentaries in the media over the four months between November 2014 and February 2015 argued that SSA was not an issue to be handled by a state intent on criminalising through punitive measures. Rather it was revealed to be a matter for discussion at the level of communities, organisations, and the UK National Health Service (NHS), where sex selection and discrimination against female children, before and after birth, could more effectively be addressed. To argue that SSA is not an issue for communities, and women with pressures to have sons, would simply be an omission (Eklund and Purewal, 2017). Also, attention to the 'iron fist' of the state in relation to SSA also requires a necessary examination of the 'invisible hand' of the market (Wacquant, 2011) which not only sells and provides SSA services but, where cultural and economic biases against females exist, also places overt, coercive, and/or indirect pressure on women to 'produce' sons (Figures 2 and 3).

\section{FIGURE 2}

\section{FIGURE 3}

However, as the outcomes of the 2015 opposition to the Abortion Amendment Act highlighted, responses to SSA in both demand and supply must involve and be supported from within the communities and organisations best placed to address the underlying issues, and not through criminalisation.

\section{The Swedish case: Protecting the right to abortion}

Abortion upon the request of the pregnant woman has been legal in Sweden since 
This is the version of the article accepted for publication in Global Public Health published by Taylor \& Francis and available online 14 Feb 2017 at: http://dx.doi.org/10.1080/17441692.2017.1289230

Accepted version downloaded from SOAS Research Online: https://eprints.soas.ac.uk/23603/

1975. Abortion is available before week 18 of gestation has been completed. After that, the National Board of Health and Welfare needs to approve the abortion, but it cannot approve abortion if the foetus is considered viable, unless the life or health of the woman is seriously threatened. It is effectively legal to undergo SSA in Sweden, since Swedish law grants women the right to request information generated through prenatal testing, including when such testing entails the sex of the foetus. Moreover, medical doctors do not have the right to reject performing an abortion on moral grounds. A woman who wishes to terminate her pregnancy is offered counselling, but it is not mandatory. Hence, the EU resolution of 2013 which suggests criminalising SSA "without prior and informed consent or understanding of the procedure by the women” (EU, 2013b, para. 34) is incompatible with Swedish abortion law.

Although SSA is not illegal, the Swedish government has expressed a critical stance towards the practice. In a report by the Foreign Affairs Committee stated the following:

The practice of prenatal sex-discrimination, i.e. the abortion of female foetuses, is an expression of patriarchal and social structures, and unequal gender relations stemming from them, which are prevalent in many parts of the world. (Swedish Parliament, 1994)

The policy framework of the Council of Europe has spurred several initiatives to amend Swedish law to restrict sex-selection. In 2006, ten representatives of the Christian Democrats (CD) party put forward a motion suggesting that Sweden should ratify the 1997 Convention for the Protection of Human Rights and Dignity of the Human Being with regard to the Application of Biology and Medicine: Convention on Human Rights and Biomedicine (CD, 2006). The motion pleads for guidelines to be developed so that prenatal diagnosis information shared with the pregnant woman 
This is the version of the article accepted for publication in Global Public Health published by Taylor \& Francis and available online 14 Feb 2017 at: http://dx.doi.org/10.1080/17441692.2017.1289230

Accepted version downloaded from SOAS Research Online: https://eprints.soas.ac.uk/23603/

does not entail any information that can encourage selective abortion, such as the sex, unless the information is relevant to the health of the foetus. It also suggested that:

Sex determination during PGD [pre-implantation genetic diagnosis] should only be allowed in the context of diagnosing for sex-related inherited disease, where no cure or treatment of the disease is available. (CD, 2006, item 6; authors' translation from Swedish)

The 2006 motion was however rejected by the Swedish parliament. In 2012 the Swedish Democrats (SD), a nationalist-populist party, took on the topic of regulating SSA. In Motion 2011/12:U16, the Swedish Democrats suggested that in accordance with the Council of Europe Resolution 1829 on Prenatal sex-selection of 2011, Sweden should introduce rules which would make it harder to access SSA (SD, 2012). The 2012 motion, as follows, also included reference to other countries, echoing the 'Asian turn':

Also in Sweden have abortions been performed on grounds of sex-selection. Since Sweden has the most liberal abortion law in Europe it is possible to find out the sex of the child during regular ultrasound scans and to freely request abortion until week 18. There are reports that women from other countries travel to Sweden to undergo SSA. That girls or boys can be de-selected before birth is a serious act of discrimination based on sex that Sweden should work against. One step in the right direction would be that parents are not informed about the sex of the child until week 22, when abortion is not available except for cases of serious hereditary disease. Several regions [referring to state-funded health services] in Sweden have an explicit policy not to determine sex during the first ultrasound [week 12]. In order to prevent SSA in accordance with Resolution 1829 this should be a policy covering the whole country and enshrined in health jurisdiction. It is possible that parents through other means find out the sex of the child, but it should be the policy that state-funded health services do no contribute to SSA. (SD, 2012, Motion 2011/12:U16)

Later the same year, the Christian Democrats put forward yet another motion, also 
This is the version of the article accepted for publication in Global Public Health published by Taylor \& Francis and available online 14 Feb 2017 at: http://dx.doi.org/10.1080/17441692.2017.1289230

Accepted version downloaded from SOAS Research Online: https://eprints.soas.ac.uk/23603/

making reference to the Council of Europe Resolution 1829 on Prenatal sex-selection of 2011, and the occurrence of SSA in other countries, most notably in Asia, drawing upon the 'gendercide’ and Asian turn discourses. Representatives of the Christian Democrats again put forward a resolution urging the Swedish parliament to declare the position that prenatal sex-selection must not take place in Sweden, and to work towards developing guidelines with regards to how information about foetal sex can be shared with the pregnant woman in ways that do not jeopardise the principle of non-discrimination (CD, 2012). Both motions were rejected, suggesting that the Swedish Parliament was not prepared to commit to any layering of the abortion law by restricting the right to information a woman has in order to make decisions about abortion. Yet, it should be noted that locally, health services have introduced policies that foetal sex information is not shared with the pregnant woman. Yet, different from the UK, the conservative parties have not petitioned for criminalising SSA, but have pleaded for restricting access to foetal sex information in order to set a barrier to SSA. Ideationally, the Swedish Democrats have evoked the Asian turn and foreign women as 'deviant aborters', while the Christian Democrats have also evoked the gendercide turn. Moreover, the Council of Europe Resolution 1829 on Prenatal sex-selection has been instrumental in legitimising these ideas.

There is no data on SSA in Sweden, and abortion statistics are only reported by age of woman, method of abortion, number of previous abortions and duration of gestation. In early 2013 the National Board of Health and Welfare decided to stop collecting statistics on abortion over concern regarding what information was gathered. Possibly, the information gathered was too detailed and therefore not compatible with legislation surrounding the use of personal data. ${ }^{13}$ After an investigation, the National Board of Health and Welfare in consultation with The Swedish Data Protection 
This is the version of the article accepted for publication in Global Public Health published by Taylor \& Francis and available online 14 Feb 2017 at: http://dx.doi.org/10.1080/17441692.2017.1289230

Accepted version downloaded from SOAS Research Online: https://eprints.soas.ac.uk/23603/

Authority decided that statistics should be collected, but in a less detailed manner. Instead of collecting birth year and birth month of each woman, the age of the woman was collected based on age cohort (at 5 year intervals) and instead of noting which district a woman lived in, only the municipality was noted. ${ }^{14}$ As of 1 January 2014, statistics were gathered again based on these new principles, which makes it impossible to trace the identity of the woman, and to monitor if for example women of a certain ethnic group or country of origin is over-represented among late-term abortion. Recently, however, the course changed with regards to data collection on abortion; and as of 1 October 2016 the Swedish Patient Register will record the social security number, residence, and marital status of all women who have an abortion in Sweden (GP, 2016). Ideationally, reasons for including information on abortion are motivated by an ambition to improve abortion-related health services. Moreover, it is argued that abortion should not be stigmatised and should be regarded as any other type of medical intervention. Yet, the change can be interpreted as partly enabling a following through on the recommendations from the European Parliament to 'identify clinics in Europe that conduct sex-selective abortions, provide statistics on this practice' (EU, 2013b, para. 18). Although the Swedish Patient Register only registers abortion services performed by a medical doctor, if all abortions are included in the future, the register will potentially be able to provide detailed abortion statistics with regards to a wide range of sociodemographic characteristics of the mother, including the sex of previous children, which can be used as proxies for SSA.

\section{TABLE 2}

Currently, the only proxy indicator available for estimating SSA is SRB. As noted in Figure 1, SRB has hovered around 106 in Sweden since early 1960s. As in 
This is the version of the article accepted for publication in Global Public Health published by Taylor \& Francis and available online 14 Feb 2017 at: http://dx.doi.org/10.1080/17441692.2017.1289230

Accepted version downloaded from SOAS Research Online: https://eprints.soas.ac.uk/23603/

the UK, the SRB among mothers born outside Sweden is within the range of 103-107 regardless of birth country of mother, as Table 2 illustrates. Thus, the data on SRB does not suggest that women of immigrant backgrounds are 'deviant aborters’. Moreover, as evident in Figure 4 below, the proportion of abortions that take place before week 7 of gestation has increased markedly since the 1980s. Likewise, the proportion of abortions which take place after week 12 has dropped, from 8.8 in 1985 to 6.6 in 2015. Yet, over the same period of time the proportion of abortions which take place after week 18 has increased modestly, from 0.8 to 1.1 percentage points.

\section{FIGURE 4}

In 2015, the Swedish Democrats once more tabled a motion referring to the 2011 resolution of the Council of Europe, proposing changing the Swedish law to allow health staff to refuse to perform abortion services right for health, and that the sex of the foetus is not communicated to parents until week 22 (SD, 2015). The motion was not approved. Then again, in 2016 the Swedish Democrats tabled a motion where it is suggested that in order to prevent SSA and other selective abortions, abortion beyond week 18 of gestation should not be approved on a 'praxis basis' (SD, 2016). These recent developments suggest that despite lack of evidence that SSA is taking place, the efforts of layering the Swedish abortion policy are on-going.

\section{Towards a broader evidence-base}

As the analysis of the European policy framework and developments in the two cases of Sweden and the UK have shown, there is evidence for both attempts and readiness for conversion and layering of abortion policies by evoking the practice of SSA. 
This is the version of the article accepted for publication in Global Public Health published by Taylor \& Francis and available online 14 Feb 2017 at: http://dx.doi.org/10.1080/17441692.2017.1289230

Accepted version downloaded from SOAS Research Online: https://eprints.soas.ac.uk/23603/

However, although there is evidence for institutional change in abortion policy at the European level, there is as of yet no changes in the institution of abortion policy in Sweden and the UK. Although the lack of evidence that SSA is taking place (see further Tables 1 and 2 and Figure 1) possibly prevents such change, other types of evidence should also be brought into the debates about evidence-based policy making. In the case of SSA, lessons can be learnt from the biomedical turn and the pitfalls of the gendercide turn.

First of all, sex-selective abortion requires two procedures which tend to be de-linked in time and space. Often, foetal sex is determined at one service delivery point and the pregnancy terminated elsewhere or by another service provider. In practice, this makes it hard for a service provider to ascertain whether or not an abortion is motivated by sex-selection (Hesketh, 2011; Menon, 1995). In this light, the EU resolution on gendercide (EU, 2013b), which suggests to identify clinics that conduct SSA and to provide statistics on SSA seems feeble.

Second, technology for foetal sex-determination is increasingly sophisticated and accurate. Today, blood tests of the pregnant women and analysis of the tissue from the placenta can identify foetal sex in week 7-9 of gestation, and ultrasound screening in week 13 (Devaney, Palomaki, Scott, and Bianchi, 2011). In the US, for example, foetal sex-determination home-testing kits for use in week 5 of gestation have become commercially available and are advertised widely (Bianchi, 2006). As long as first trimester foetal sex-determination technology is in great supply, SSA will be difficult to prevent.

Third, restricting access to SSA may violate women's nationally established legal right to abortion. According to the UN Department of Economic and Social Affairs 
This is the version of the article accepted for publication in Global Public Health published by Taylor \& Francis and available online 14 Feb 2017 at: http://dx.doi.org/10.1080/17441692.2017.1289230

Accepted version downloaded from SOAS Research Online: https://eprints.soas.ac.uk/23603/

(UNDESA), in 30 percent of the world's countries abortion is available upon request up to at least week 12 of gestation, and in 86 percent it is available to protect a woman's mental health (UNDESA, 2013). This linkage is not lost on anti-abortion activists who, using the 'prenatal sex-selection as gendercide’ debate as a lever for restricting abortion rights, propose that 'we--the pro-life movement--adopt as our next goal the banning of sex- and race-selective abortion’ (Mosher, 2008).

Fourth, restricting access to SSA may prompt women determined to choose the sex of their child to resort to other methods of sex selection. With the advancement of biotechnology, women can select the sex of their child through pre-implantation genetic diagnosis, involving sperm-sorting by sex (Thornton, 2000) and sex selection of embryos (Sermon, Van Steirteghem, and Liebaers, 2004). Hence, pre-implantation genetic diagnosis may contribute to 'missing girls' as much as SSA.

Finally, it is not unreasonable to think that prenatal sex-selection replaces postnatal sex-selection to some degree (Warren, 1985; Arnold, Kishor, and Roy, 2002). Restricting access of SSA may therefore potentially have devastating effects on the rights of the girl child, pointing at a major pitfall in the 'gendercide' discourse.

\section{Conclusion}

Neoliberal Europe provides fertile ground for the moral panic surrounding SSA.

However, there is yet a lack of evidence that SSA is actually taking place in Europe, except in a few countries where the SRB is skewed. This does not mean that SSA will not become a practice of concern in other European countries, such as Sweden and the UK, but it means that policy makers should carefully consider evidence before 
This is the version of the article accepted for publication in Global Public Health published by Taylor \& Francis and available online 14 Feb 2017 at: http://dx.doi.org/10.1080/17441692.2017.1289230

Accepted version downloaded from SOAS Research Online: https://eprints.soas.ac.uk/23603/

initiating abortion policy changes. The circulation of the 'gendercide' and Asian demographic discourses throughout Europe, as reflected in policy discourse related to prenatal sex-selection and abortion, suggests that ideational processes are significant in underpinning a moral panic surrounding SSA. Furthermore, as we have highlighted, where political interests have found a space to question existing abortion laws, they have articulated the populist rhetoric of 'gendercide' and the Asian demographic 'threat' to mobilise political interest in SSA; as occurred in the UK with the right-wing Conservative anti-abortion lobby, and in Sweden with the Christian Democrats and right-wing populist Swedish Democrats. In both the UK and Sweden, challenges to national abortion legislation highlighted alleged ambiguities in national laws, cited European legislation, and invoked the 'gendercide' and Asian demographic turn in their attempt to change abortion policies.

This analysis has demonstrated the importance of ideational process in shaping propositions and resolutions on prenatal sex-selection and abortion. It has also found ample evidence that both processes of conversion and layering on prenatal sexselection are discernible, even if institutional change has not yet occurred in the two country cases presented. Yet, we argue that analysing these processes of attempted change is important for two reasons; (1) in order to understand what direction abortion policy may be taking, and (2) to identify the need for counter-movement and contribute to the mobilisation of parties committed to keeping abortion legally available to all through the public health system, regardless of their motives and reasons. Reducing the number of missing girls and women by restricting access to SSA today would not only be operationally difficult, legally questionable, and curb women's sexual and reproductive rights; it may also force women to resort to unsafe abortion. Where there is demand for sex selection, however, it may also lead to a 
This is the version of the article accepted for publication in Global Public Health published by Taylor \& Francis and available online 14 Feb 2017 at: http://dx.doi.org/10.1080/17441692.2017.1289230

Accepted version downloaded from SOAS Research Online: https://eprints.soas.ac.uk/23603/

surge in other methods of sex selection. Ultimately, therefore, criminalisation and disciplining SSA achieve no aims other than fulfilling the functions of the neoliberal state. Though it may lead to a reduction in the frequency of SSA, it is questionable whether it would reduce the number of 'missing girls'.

\section{Acknowledgements}

We are grateful for invaluable comments from three anonymous peer reviewers on an earlier draft of this article. We also thank Karin Gottvall at The National Board of Health and Welfare in Swedish for providing useful background information on abortion in Sweden.

\section{Reference list}

Arnold, F., Kishor, S., and Roy, T.K. (2002). Sex-Selective Abortions in India. Population and Development Review, 28, 759-785. doi: 10.1111/j.17284457.2002.00759.x

Béland, D. (2007). Ideas and Institutional Change in Social Security: Conversion, Layering, and Policy Drift. Social Science Quarterly, 88, 20-38. doi: 10.1111/j.1540-6237.2007.00444.x

Bianchi, D.W. (2006). At-home fetal DNA gender testing: Caveat emptor. Obstet Gynecol., 107, 216-218. doi:10.1097/01.AOG.0000199427.83503.d0

Christian Democrats (2006). Med anledning av prop. 2005/06:64, Genetisk integritet m.m. [Motion 2005/06:So22 with regards to proportion 2005/06:64 on Genetic integrity etc. put forward by the Christian Democrats , 3 February 2006.]

Accessed 5 February 2016 at: http://www.riksdagen.se/sv/dokumentlagar/dokument/motion/med-anledning-av-prop-20050664genetisk_GT02So22 
This is the version of the article accepted for publication in Global Public Health published by Taylor \& Francis and available online 14 Feb 2017 at: http://dx.doi.org/10.1080/17441692.2017.1289230

Accepted version downloaded from SOAS Research Online: https://eprints.soas.ac.uk/23603/

Christian Democrats (2012). Könsselektiva aborter, Motion 2012/13:So488. [Motion on Sex-selective abortion, tabled by the Christian Democrats, 5 October 2012.] Accessed 5 February 2016 at: http://www.riksdagen.se/sv/dokumentlagar/dokument/motion/konsselektiva-aborter_H002So488

Council of Europe (1997). Convention for the Protection of Human Rights and Dignity of the Human Being with regard to the Application of Biology and Medicine: Convention on Human Rights and Biomedicine. European Treaty Series - No. 164, Accessed 20 May 2016 at https://rm.coe.int/CoERMPublicCommonSearchServices/DisplayDCTMConte $\underline{\text { nt?documentId }=090000168007 \text { cf98 }}$

Council of Europe (2002). Recommendation of the Committee of Ministers to member states on the protection of women against violence, Adopted by the Committee of Ministers on 30 April 2002 at the 794th meeting of the Ministers’ Deputies, Council of Europe. Accessed 20 May 2016 at https://wcd.coe.int/ViewDoc.jsp?p=\&Ref=Rec(2002)5\&Language=lanEnglish $\underline{\text { \&er}=\text { original \&Site }=\mathrm{CM} \& B \text { ackColorInternet }=\text { DBDCF2\&BackColorIntranet }}$ $=$ FDC864\&BackColorLogged=FDC864\&direct=true

Council of Europe (2010). Motion on 'Sex-selective Abortion - 'Gendercide'” doc.12258, presented to the Parliamentary Assembly of the Council of Europe, 11 May 2010. Accessed 20 May 2016 at http://semanticpace.net/tools/pdf.aspx?doc=aHR0cDovL2Fzc2VtYmx5LmNvZS5pbnQvbnc veG1sL1hSZWYvWDJILURXLWV4dHIuYXNwP2ZpbGVpZD0xMjg1NCZ sYW5nPUVO\&xsl=aHR0cDovL3NlbWFudGljcGFjZS5uZXQvWHNsdC9Q ZGYvWFJlZi1XRC1BVC1YTUwyUERGLnhzbA==\&xsltparams=ZmlsZWl kPTEyODU0

Council of Europe (2011a). Report on 'Prenatal sex selection' doc.12715, issued by the Committee on Equal Opportunities for Women and Men of the Council of 
This is the version of the article accepted for publication in Global Public Health published by Taylor \& Francis and available online 14 Feb 2017 at: http://dx.doi.org/10.1080/17441692.2017.1289230

Accepted version downloaded from SOAS Research Online: https://eprints.soas.ac.uk/23603/

Europe, 16 September 2011. Accessed 20 May 2016 at http://semanticpace.net/tools/pdf.aspx?doc=aHR0cDovL2Fzc2VtYmx5LmNvZS5pbnQvbnc veG1sL1hSZWYvWDJILURXLWV4dHIuYXNwP2ZpbGVpZD0xMzE1OC ZsYW5nPUVO\&xsl=aHR0cDovL3NlbWFudGljcGFjZS5uZXQvWHNsdC9 QZGYvWFJIZi1XRC1BVC1YTUwyUERGLnhzbA==\&xsltparams=ZmlsZ WlkPTEzMTU4

Council of Europe (2011b). Resolution 1829 on Prenatal sex selection. Adopted by Parliamentary Assembly of the Council of Europe, 3 October 2011. Accessed 20 May 2016 at http://assembly.coe.int/nw/xml/XRef/Xref-XML2HTMLen.asp?fileid $=18020 \&$ lang $=$ en

Council of Europe (2011c). Recommendation 1979 (2011b) on Prenatal sex selection. Final version, issued by the Parliamentary Assembly of the Council of Europe, 3 October 2011. Accessed 20 May 2016 at http://assembly.coe.int/nw/xml/XRef/Xref-XML2HTMLen.asp?fileid=18021\&lang=en

Council of Europe (2015). The practice of prenatal selection by sex. Written question No. 685 to the Committee of Ministers, Council of Europe, from Mr Valeriu Ghiletchi, Republic of Moldova, Doc. 13783, 4 May 2015. Accessed 20 May 2016 at http://assembly.coe.int/nw/xml/XRef/Xref-XML2HTMLen.asp?fileid $=21771 \&$ lang $=$ en

Department of Health (2014). Guidance in Relation to Requirements of the Abortion Act 1967. Accessed at: https://www.google.com/url?sa=t\&rct=j\&q=\&esrc=s\&source=web\&cd=1\&ve d=0ahUKEwiOrPKP59LPAhUFVRQKHbyLBPsQFggeMAA\&url=https\%3A \%2F\%2Fwww.gov.uk\%2Fgovernment\%2Fuploads\%2Fsystem\%2Fuploads\% 2Fattachment_data\%2Ffile\%2F313459\%2F20140509__Abortion_Guidance_Document.pdf\&usg=AFQjCNHBSwuVUcQq7posR55d Oestf0ZUrQ 
This is the version of the article accepted for publication in Global Public Health published by Taylor \& Francis and available online 14 Feb 2017 at: http://dx.doi.org/10.1080/17441692.2017.1289230

Accepted version downloaded from SOAS Research Online: https://eprints.soas.ac.uk/23603/

Devaney, S. A., Palomaki, G. E., Scott, J. A., and Bianchi, D. W. (2011). Noninvasive fetal sex determination using cell-free fetal DNA: A systematic review and meta-analysis. JAMA, 306, 627-636. doi:10.1001/jama.2011.1114

Dubuc, S., and Coleman, D. (2007). An Increase in the Sex Ratio of Births to Indiaborn Mothers in England and Wales: Evidence for Sex-Selective Abortion. Population and Development Review, 33, 383-400. doi:10.1111/j.17284457.2007.00173.x

Eklund, L. and N. Purewal (2017). The Bio-Politics of Population Control and Sex Selective Abortion in China and India. Feminism and Psychology. Volume 1, Issue 27. Accessed via http://eprints.soas.ac.uk/23079/

Eklund, L. (2017) Is there evidence for 'deviant aborters' in Sweden? Analysing sex ratio at birth1978-2015 by birthplace of mother. Working paper.

European Union (2010). European Parliament resolution on the Annual Report on Human Rights in the World 2009 and the European Union's policy on the matter, 16 December 2010. Accessed 20 May 2016 at http://eurlex.europa.eu/legalcontent/EN/TXT/?uri=uriserv:OJ.CE.2012.169.01.0081.01.ENG\&toc=OJ:C:2 012:169E:TOC

European Union (2013a). Gendercide: the missing women? Report by the Committee on Women's Rights and Gender Equality, European Parliament (2012/2273(INI)), 28 June 2013. Accessed 11 November 2013 at: http://www.europarl.europa.eu/sides/getDoc.do?pubRef=//EP//NONSGML+REPORT+A7-2013-0245+0+DOC+PDF+V0//EN

European Union (2013b). Gendercide: the missing women? Resolution P7_TA(2013)0400, European Parliament, 8 October 2013. Accessed 11 November 2013 at: http://www.europarl.europa.eu/sides/getDoc.do?pubRef=//EP//TEXT+TA+P7-TA-2013-0400+0+DOC+XML+V0//EN 
This is the version of the article accepted for publication in Global Public Health published by Taylor \& Francis and available online 14 Feb 2017 at: http://dx.doi.org/10.1080/17441692.2017.1289230

Accepted version downloaded from SOAS Research Online: https://eprints.soas.ac.uk/23603/

Foucault, M. (1977). Discipline and Punish: The Birth of the Prison. Penguin: London.

Foucault, M. (2009). 25 January 1978. In M.S. Foucault, F. Ewald, and A. Fontana (Eds.) Security, territory and population: Lectures at the Collège de France 1977-1978. (G. Burchell, Trans.). New York: Palgrave-Macmillan.

Ginsburg, F.D., and Rapp, R. (1995). Conceiving the New World Order: The Politics of Global Reproduction. University of California Press: Berkeley and Los Angeles.

Göteborgsposten (GP) (2016). Register will enable better abortion care [Register ska ge bättre abortvård]. Accessed 1 October 2016, http://www.gp.se/nyheter/sverige/register-ska-ge-b\%C3\%A4ttreabortv\%C3\%A5rd-1.3833493

Hall, P. A. (1993). Policy paradigms, social learning, and the state: the case of economic policymaking in Britain. Comparative politics, 25(3): 275-296.

Hesketh, T. (2011). Selecting sex: the effect of preferring sons. Early human development, 87(11), 759-761.

Hoggart, L. (2015). Abortion Counselling in Britain: Understanding the Controversy. Sociology Compass, 9, 365-378. doi:10.1111/soc4.12256

Keil, T. J., and Andreescu, V. (1999). Fertility policy in Ceausescu's Romania. Journal of Family History, 24, 478-492.

Lee, E.J. (2017). Constructing Abortion as a Social Problem: Sex selection and the British Abortion Debate. Feminism and Psychology. Volume 1, Issue 27. Accessed via http://kar.kent.ac.uk/57294/1/\%27Constructing\%20abortion\%20as\%20a\%20s 
This is the version of the article accepted for publication in Global Public Health published by Taylor \& Francis and available online 14 Feb 2017 at: http://dx.doi.org/10.1080/17441692.2017.1289230

Accepted version downloaded from SOAS Research Online: https://eprints.soas.ac.uk/23603/

ocial\%20problem\%27\%20\%28Feminism\%20and\%20Psychology\%20prepublication\%20version\%29.pdf

Macklin, R. (1999). Against relativism: Cultural diversity and the search for ethical universals in medicine. New York, NY: Oxford University Press.

Mosher, S. (2008). A New Front in the Abortion Wars. Weekly Briefing: 2008 (v10). Accessed Nov 6, 2013 via http://www.pop.org/content/september-30-a-newfront-in-the-abortion-wars-915

Menon, N. (1995). The impossibility of 'justice’: female foeticide and feminist discourse on abortion. Contributions to Indian Sociology, 1-2, 369-392. doi:10.1177/0069966795029001017

National Board of Health and Welfare (2016). Statistik om aborter 2015. [Statistics on abortion 2015.] Accessed 20 May 2016 at: http://www.socialstyrelsen.se/publikationer2016/2016-5-20

Nie, J. B. (2005). Behind the silence: Chinese voices on abortion. Lanham, ML: Rowman and Littlefield.

Purewal N. (2010) Son Preference: Sex Selection, Gender and Culture in South Asia. Oxford: Berg.

Roberts, D. (1997). Killing the Black Body: Race, Reproduction and the Meaning of Liberty. Pantheon: New York.

Sen, A. (2003). Missing women—revisited. BMJ, 327. doi:10.1136/bmj.327.7427.1297

Sermon, K., Van Steirteghem, A., and Liebaers, I. (2004). Preimplantation genetic diagnosis. The Lancet, 363, 1633-1641. doi:10.1016/S0140-6736(04)16209-0 
This is the version of the article accepted for publication in Global Public Health published by Taylor \& Francis and available online 14 Feb 2017 at: http://dx.doi.org/10.1080/17441692.2017.1289230

Accepted version downloaded from SOAS Research Online: https://eprints.soas.ac.uk/23603/

Sheldon, S. (2015). The Decriminalisation of Abortion: An Argument for Modernisation. Oxford Journal of Legal Studies, 1-32. doi:10.1093/ojls/gqv026

Smyth, L. (2005). Abortion and Nation: The Politics of Reproduction in Contemporary Ireland. Ashgate: Aldershot.

Swedish Parliament (1994). Utrikesutskottets betänkande 1993/94:UU15, Internationellt utvecklingssamarbete [Report of the Foreign Affairs Committee 1993/94:UU15, International Development Cooperation.] Accessed 5 February 2016 at: http://www.riksdagen.se/sv/dokumentlagar/arende/betankande/internationelltutvecklingssamarbete_GH01UU15/html

Swedish Democrats (2012). Med anledning av redog. 2011/12:ER1 Från Sveriges delegation vid Europarådets parlamentariska församling. [Motion to the Swedish Parliament on 2011/12:U16 with regards to account 2011/12:ER1 from the Swedish delegation to the Parliamentary Assembly of the Council of Europe, tabled by the Swedish Democrats, 30 March 2012.] Accessed 5

February 2016 at: http://www.riksdagen.se/sv/dokumentlagar/dokument/motion/med-anledning-av-redog-201112er1-fran$\underline{\text { sveriges_GZ02U16 }}$

Swedish Democrats (2015). Könsselektiva aborter, Motion 2015/16:2072. [Motion on Sex-selective abortion, tabled by the Swedish Democrats, 6 October 2015.] Accessed 5 February 2016 at: https://www.riksdagen.se/sv/dokumentlagar/dokument/motion/konsselektiva-aborter_H3022072

Swedish Democrats (2016). Könsselektiva och andra utsorterande aborter, 
This is the version of the article accepted for publication in Global Public Health published by Taylor \& Francis and available online 14 Feb 2017 at: http://dx.doi.org/10.1080/17441692.2017.1289230

Accepted version downloaded from SOAS Research Online: https://eprints.soas.ac.uk/23603/

Motion 2016/17:2902 [Motion on sex-selective and other selective abortions, tabled by the Swedish Democrats, 5 October 2016], Accessed 12 October 2016 at http://www.riksdagen.se/sv/dokumentlagar/dokument/motion/_H4022902

Thelen, K. (2004). How institutions evolve: The political economy of skills in Germany, Britain, the United States, and Japan. Cambridge University Press.

Thornton, K. (2000). Advances in assisted reproductive technologies. Obstet Gynecol Clin North Am, 27, 517-527.

Torres-Coronas, T., Belzunegui-Eraso, A., and Moreno-Gené, J. (Eds.) (2015).

Finding Solutions for a Post-Crisis Society. Tarragona: Publicacions Universitat Rovira i Virgili.

United Nations Department of Economic and Social Affairs (2013). World Abortion Policies 2013, Accessed on November 27, 2013 via http://www.un.org/en/development/desa/population/publications/pdf/policy/W orldAbortionPolicies2013/WorldAbortionPolicies2013_WallChart.pdf

Wacquant, L. (2009). Punishing the Poor: The Neoliberal Government of Social Insecurity. Durham, NC: Duke University Press.

Wacquant, L. (2011). Deadly Symbiosis: Race and the Rise of the Penal State. Boston, MA: Polity.

Warren, M.A. (1985) Gendercide: The Implications of Sex Selection, Rowman and Allanheld

Warren, M.A. (1999) ‘Sex selection: Individual choice or cultural coercion?’ In Bioethics: An anthology, ed. H. Kuhse and P. Singer, 137-42. Oxford: Blackwell. 
This is the version of the article accepted for publication in Global Public Health published by Taylor \& Francis and available online 14 Feb 2017 at: http://dx.doi.org/10.1080/17441692.2017.1289230

Accepted version downloaded from SOAS Research Online: https://eprints.soas.ac.uk/23603/ 
This is the version of the article accepted for publication in Global Public Health published by Taylor \& Francis and available online 14 Feb 2017 at: http://dx.doi.org/10.1080/17441692.2017.1289230

Accepted version downloaded from SOAS Research Online: https://eprints.soas.ac.uk/23603/

Table 1. Total births, ratio of male/female births, and average sex ratios at birth between 1969 and 2005 in England and Wales, by birthplace of mother

\begin{tabular}{|l|l|l|l|}
\hline $\begin{array}{l}\text { Birthplace of } \\
\text { mother }\end{array}$ & $\begin{array}{l}\text { Total number of } \\
\text { births }\end{array}$ & $\begin{array}{l}\text { Males/Female } \\
\text { births }\end{array}$ & Total Sex Ratio \\
\hline All birthplaces & $23,420,189$ & $\begin{array}{l}12,023,607 / 11, \\
396,582\end{array}$ & 105.5 \\
\hline $\begin{array}{l}\text { UK (England and } \\
\text { Wales, Scotland, N. } \\
\text { Ireland }\end{array}$ & 20, 282, 327 & $\begin{array}{l}10,417,453 / 9, \\
864,874\end{array}$ & 105.6 \\
\hline $\begin{array}{l}\text { US, Canada, } \\
\text { Australia, New } \\
\text { Zealand }\end{array}$ & 199,719 & $102,912 / 96,807$ & 106.3 \\
\hline $\begin{array}{l}\text { Rest of New } \\
\text { Commonwealth }\end{array}$ & 56,316 & $28,691 / 27,625$ & 103.9 \\
\hline Europe non-UK & 831,345 & $427,077 / 404,268$ & 105.7 \\
\hline Southern Africa & 45,137 & $23,093 / 22,044$ & 104.8 \\
\hline East Africa & 174,411 & $88,892 / 85,519$ & 103.9 \\
\hline Rest of Africa & 162,301 & $82,021 / 80,280$ & 102.2 \\
\hline Caribbean & 199,356 & $101,192 / 98,164$ & 104.8 \\
\hline Bangladesh & 163,484 & $82,635 / 80,849$ & 105.4 \\
\hline Pakistan & 428,707 & $219,326 / 209,381$ & 105.6 \\
\hline Far East & 58,745 & $30,173 / 28,572$ & 105.2 \\
\hline Rest of the World & 433,433 & $222,315 / 211,118$ & 105.2 \\
\hline Source: Dubcand & &
\end{tabular}

Source: Dubuc and Coleman (2007) 
This is the version of the article accepted for publication in Global Public Health published by Taylor \& Francis and available online 14 Feb 2017 at: http://dx.doi.org/10.1080/17441692.2017.1289230

Accepted version downloaded from SOAS Research Online: https://eprints.soas.ac.uk/23603/

Table 2. Total births, ratio of male/female births, and average sex ratios at birth between 1978 and 2015 in Sweden, by birthplace of mother

\begin{tabular}{|l|l|l|l|}
\hline $\begin{array}{l}\text { Birthplace of } \\
\text { mother }\end{array}$ & Male births & Female births & Total Sex Ratio \\
\hline Sweden & $1,675,233$ & $1,583,466$ & 105.80 \\
\hline Other EU/ESS & 119,803 & 113,352 & 105.69 \\
\hline $\begin{array}{l}\text { Other European } \\
\text { countries }\end{array}$ & 38,607 & 35,875 & 107.62 \\
\hline Middle East & 65,487 & 62,309 & 105.10 \\
\hline North Africa & 22,898 & 21,517 & 106.42 \\
\hline Sub-Saharan Africa & 17,053 & 16,290 & 104.68 \\
\hline Central Asia & 22,559 & 21,359 & 105.62 \\
\hline South Asia & 14,455 & 13,857 & 104.32 \\
\hline Southeast Asia & 18,775 & 17,559 & 106.93 \\
\hline East Asia & 9,136 & 8,705 & 104.95 \\
\hline Latin America & 20,551 & 19,520 & 105.28 \\
\hline North America & 4,494 & 4,211 & 106.72 \\
\hline $\begin{array}{l}\text { Australia and the } \\
\text { Pacific }\end{array}$ & 891 & 844 & 105.57 \\
\hline $\begin{array}{l}\text { Stateless or } \\
\text { unknown }\end{array}$ & 4,944 & 4,714 & 104.88 \\
\hline ALL BIRTHS & $2,034,886$ & $1,923,578$ & 105.79 \\
\hline
\end{tabular}

Source: Eklund (2017) 
This is the version of the article accepted for publication in Global Public Health published by Taylor \& Francis and available online 14 Feb 2017 at: http://dx.doi.org/10.1080/17441692.2017.1289230

Accepted version downloaded from SOAS Research Online: https://eprints.soas.ac.uk/23603/

Figure 1. Sex ratio at birth in selected European countries and EU average

1962-2012

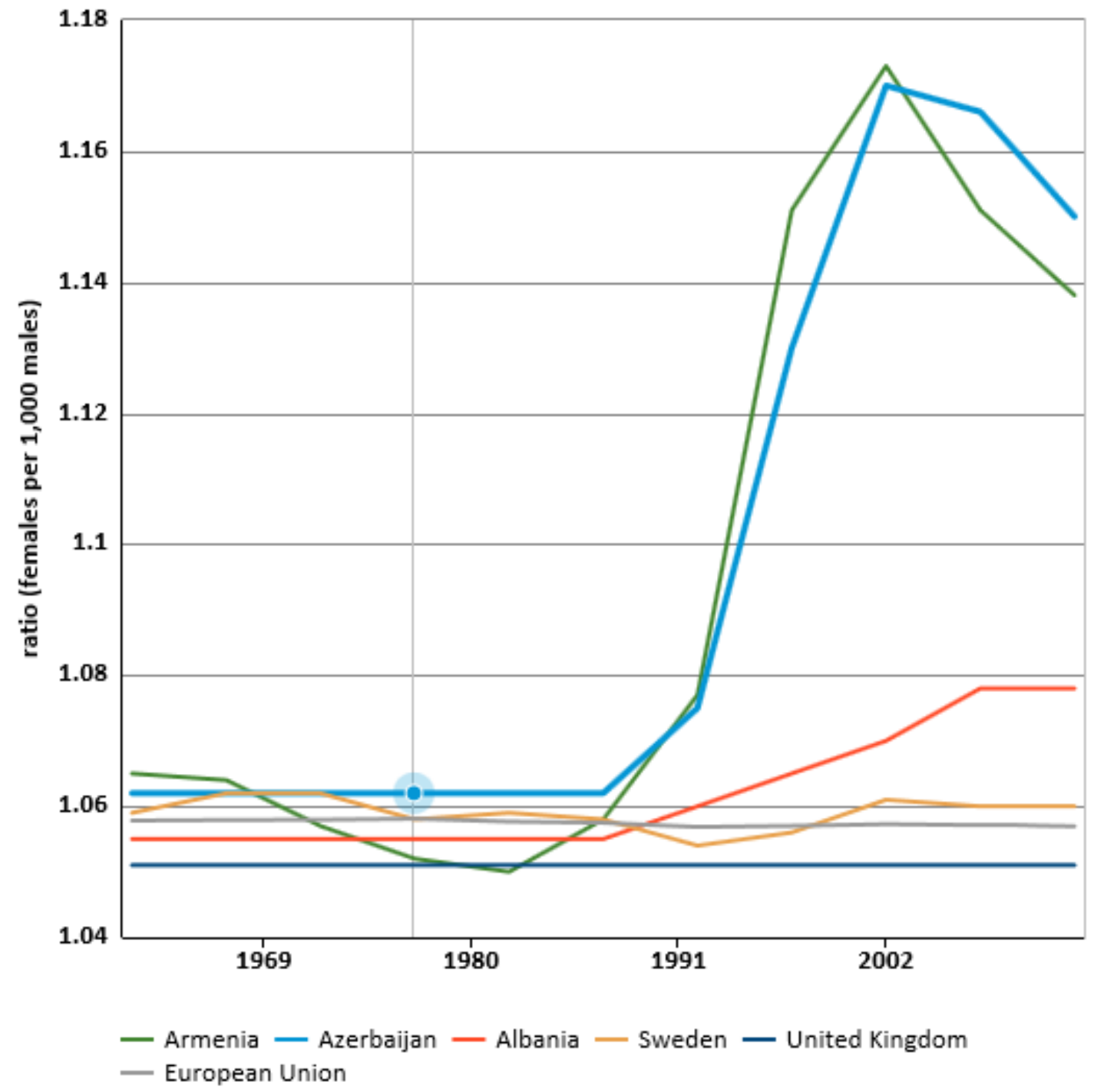

Source: Health Nutrition and Population Statistics (World Bank), September 2014.

Accessed 30 May 2016 at: https://knoema.com/WBHNPStats2014Sep/health-nutrition-andpopulation-statistics-world-bank-september-2014?tsId=1476270 
This is the version of the article accepted for publication in Global Public Health published by Taylor \& Francis and available online 14 Feb 2017 at: http://dx.doi.org/10.1080/17441692.2017.1289230

Accepted version downloaded from SOAS Research Online: https://eprints.soas.ac.uk/23603/

Figure 2. Newspaper advertisement in the UK of pre-fertilisation sex selective technologies for 'social reasons' (2001)

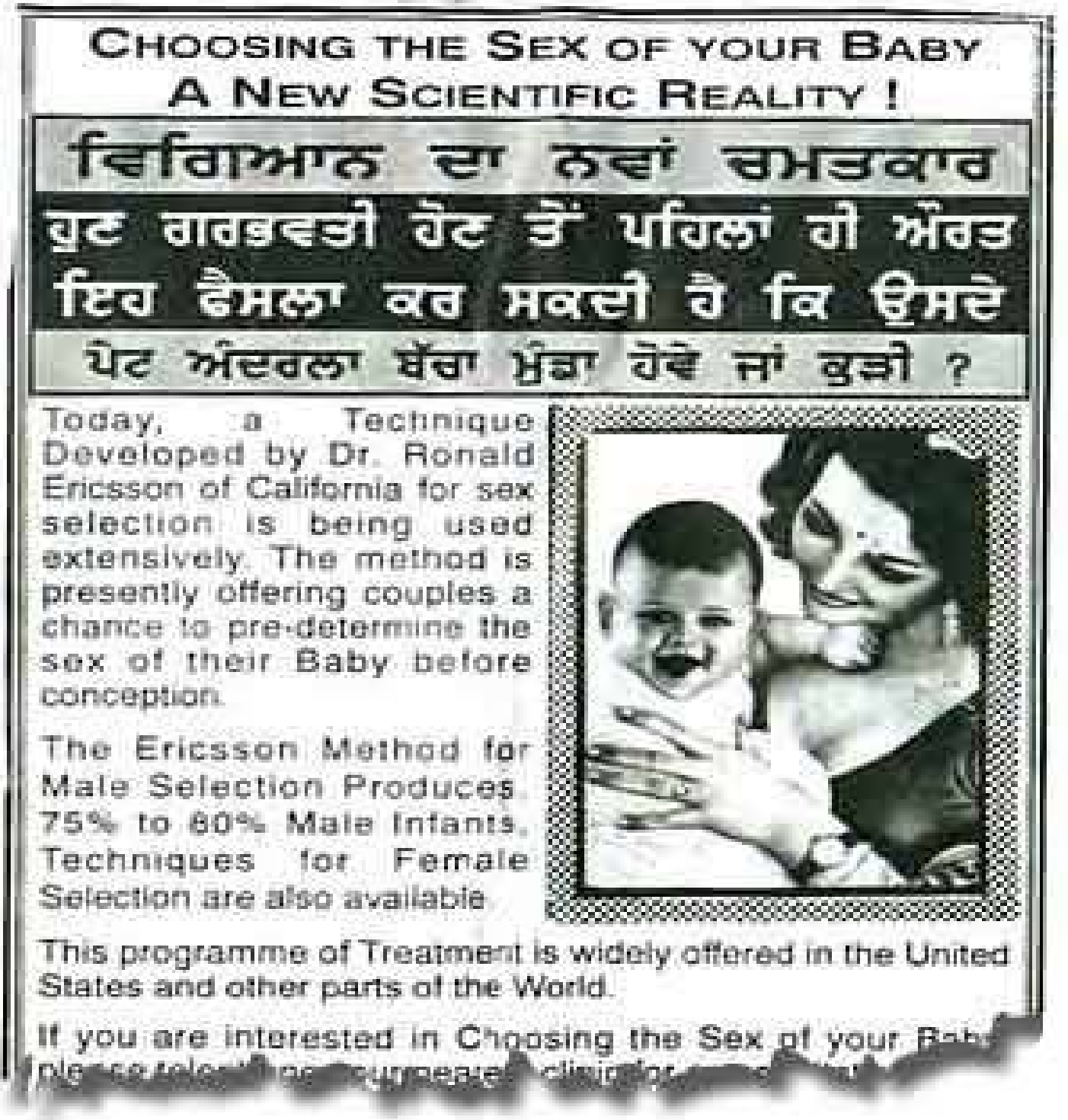

Source: Des Pardes Weekly 
This is the version of the article accepted for publication in Global Public Health published by Taylor \& Francis and available online 14 Feb 2017 at: http://dx.doi.org/10.1080/17441692.2017.1289230

Accepted version downloaded from SOAS Research Online: https://eprints.soas.ac.uk/23603/

Figure 3. Advertisement of Ultrasound for Foetal Sex Identification (2001)

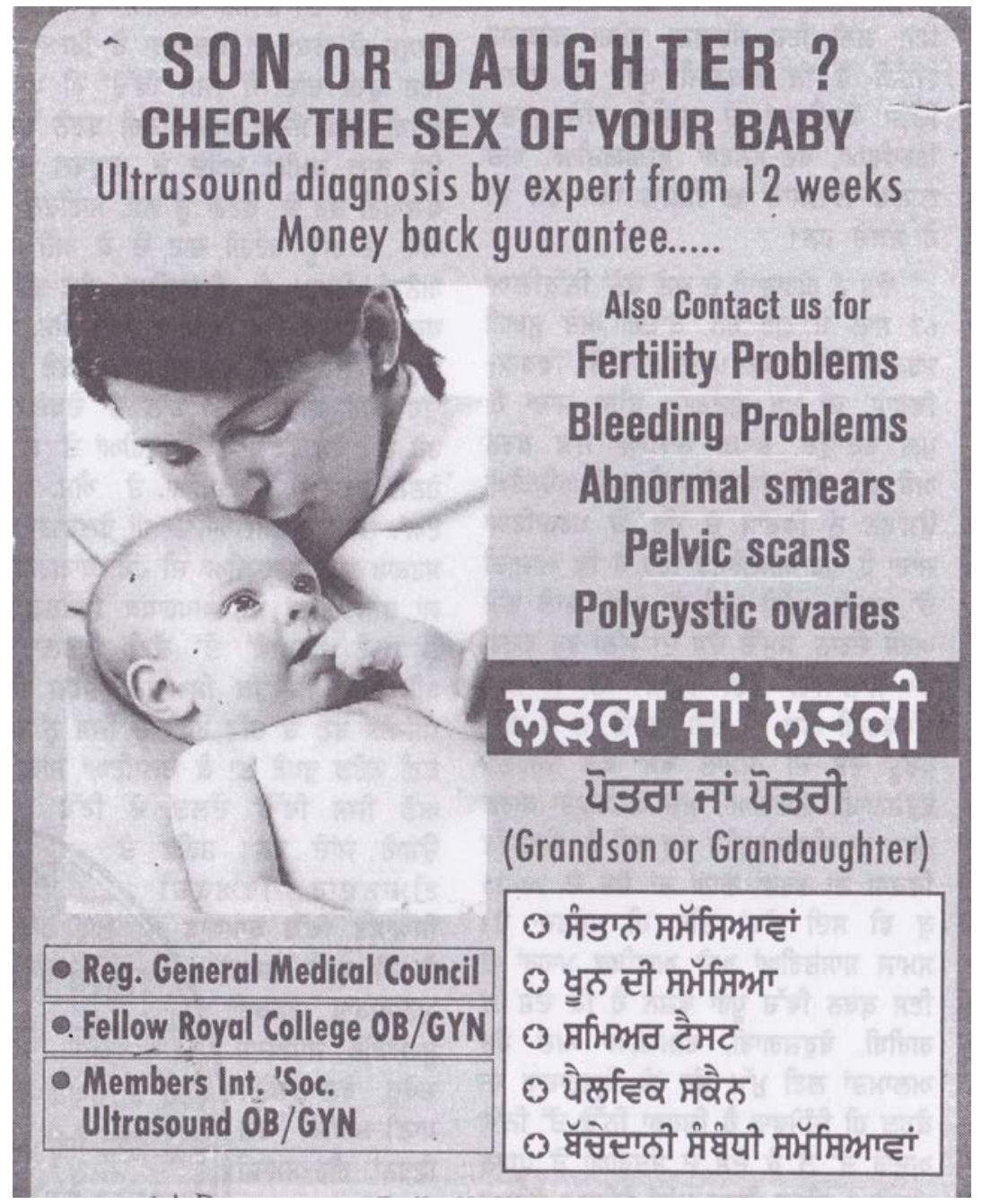

Source: Des Pardes Weekly 
This is the version of the article accepted for publication in Global Public Health published by Taylor \& Francis and available online 14 Feb 2017 at: http://dx.doi.org/10.1080/17441692.2017.1289230

Accepted version downloaded from SOAS Research Online: https://eprints.soas.ac.uk/23603/

Figure 4. Abortion according to gestation period in Sweden

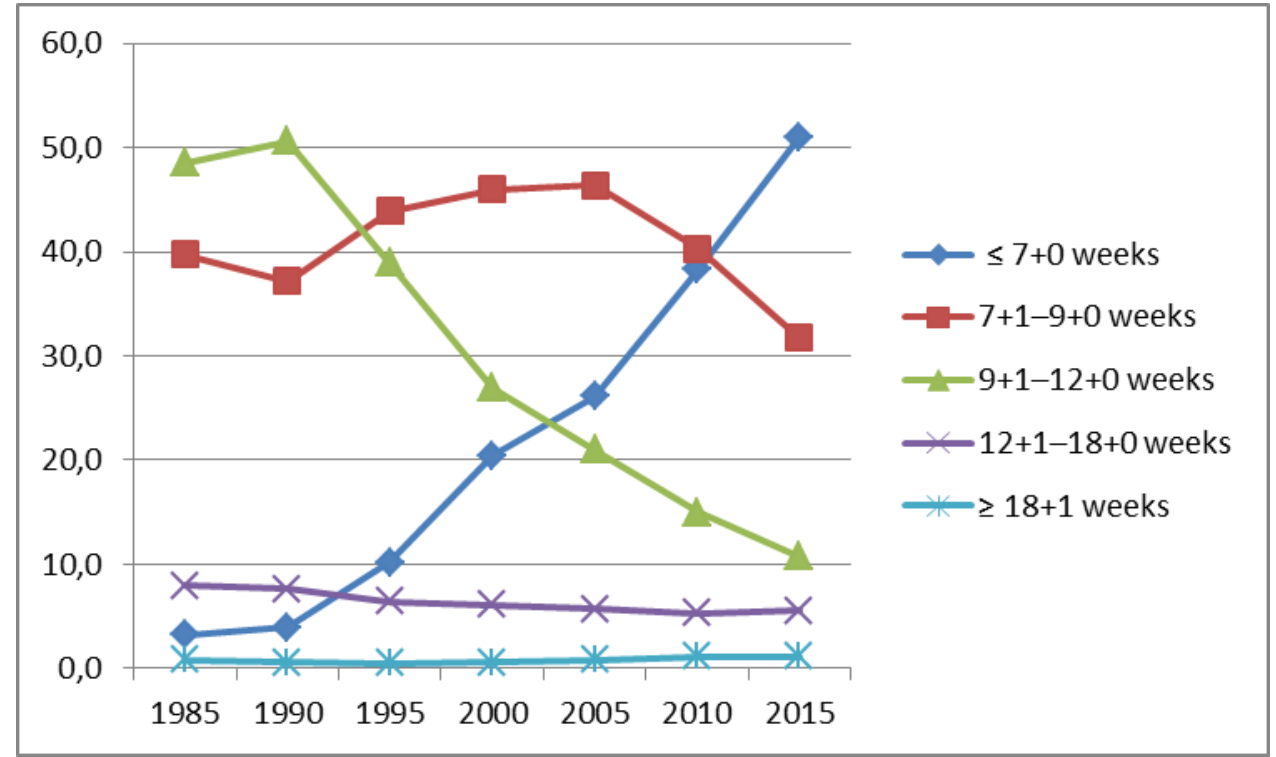

Source: National Board of Health and Welfare (2016) 
This is the version of the article accepted for publication in Global Public Health published by Taylor \& Francis and available online 14 Feb 2017 at: http://dx.doi.org/10.1080/17441692.2017.1289230

Accepted version downloaded from SOAS Research Online: https://eprints.soas.ac.uk/23603/

${ }^{1}$ Abortion is illegal in all circumstances in Malta and Ireland while it is only permitted in Poland if meant to save a woman's life or protect her physical health.

${ }^{2}$ The UK and Sweden are the two countries in Europe where the legal limit for abortion 'on demand' is the latest: 24 and 18 weeks respectively, whereas it is 10 to 12 weeks in most other countries in Europe.

${ }^{3}$ It should be noted that the UK in June 2016 voted for leaving the EU, but at the time of writing this article, UK was still a EU member state.

${ }^{4}$ Sex-selection first appeared in the 1997 Convention for the Protection of Human Rights and Dignity of the Human Being with regard to the Application of Biology and Medicine: Convention on Human Rights and Biomedicine of the Council of Europe (European Treaty Series - No. 164). Article 14 of the convention states: 'The use of techniques of medically assisted procreation shall not be allowed for the purpose of choosing a future child's sex, except where serious hereditary sex-related disease is to be avoided.' The treaty concerns medically assisted procreation, but does not refer to abortion. Out of the 47 member states of the Council of Europe, 35 states have signed and 29 states have ratified the treaty. While the UK never signed the treaty, Sweden signed it in 1999, but never ratified it.

${ }^{5}$ See http://www.hfea.gov.uk/docs/Final_sex_selection_main_report.pdf

${ }^{6}$ For a detailed and critical analysis of abortion law in the UK and the Serious Crime and Abortion Amendment Act, see Sally Sheldon (2015).

${ }^{7}$ http://www.telegraph.co.uk/women/womens-life/11362379/Gender-abortion-Its-time-forurgent-action.html

${ }^{8}$ Professor David Coleman, one of the authors of the study widely cited by the anti-abortion lobbyists behind the Serious Crime Bill amendment, was also a co-founder of the think tank Migration Watch UK. It could be inferred that the 'deviant aborters’ which are at the centre of the 2015 abortion debate are projected in the cited study through a conservative, populist migration watchdog lens as well as through a framing of 'health services under pressure’ by immigrants with deviant reproductive health issues.

${ }^{9}$ A subsequent report b the Department of Health was published in August 2015 in following up the Serious Crime Act which set out a strategy in continuing to assess how and to what extent sex-selection is being accessed in the UK 
This is the version of the article accepted for publication in Global Public Health published by Taylor \& Francis and available online 14 Feb 2017 at: http://dx.doi.org/10.1080/17441692.2017.1289230

Accepted version downloaded from SOAS Research Online: https://eprints.soas.ac.uk/23603/

https://www.gov.uk/government/uploads/system/uploads/attachment_data/file/456642/s

ex_selection_doc.pdf

${ }^{10}$ Jeena International, Karma Nirvana, Muslim Women’s Network UK and the Sharan Project were the organisations behind the campaign to highlight gendercide as an issue of interest for the UK anti-abortion lobby pushing for the Abortion Amendment Act of the Serious Crime Bill. The petition led by Jeena International was signed not only by these women's organisations but also faith organisations who did not share in the analysis with others that this represented an encroachment of the right to abortion.

${ }^{11}$ The following clauses were hence flagged up:

(1)Subject to the provisions of this section, a person shall not be guilty of an offence under the law relating to abortion when a pregnancy is terminated by a registered medical practitioner if two registered medical practitioners are of the opinion, formed in good faith-

[F1(a)that the pregnancy has not exceeded its twenty-fourth week and that the continuance of the pregnancy would involve risk, greater than if the pregnancy were terminated, of injury to the physical or mental health of the pregnant woman or any existing children of her family; or

(b)that the termination is necessary to prevent grave permanent injury to the physical or mental health of the pregnant woman; or

(c)that the continuance of the pregnancy would involve risk to the life of the pregnant woman, greater than if the pregnancy were terminated; or

(d)that there is a substantial risk that if the child were born it would suffer from such physical or mental abnormalities as to be seriously handicapped

${ }^{12} \mathrm{http}: / /$ www.independent.co.uk/voices/letters/letters-the-wrong-way-to-stop-selectiveabortion-of-girls-10057662.html?fb_ref=Default

${ }^{13} \mathrm{http}: / /$ www.socialstyrelsen.se/statistik/statistikefteramne/aborter

${ }^{14}$ http://www.socialstyrelsen.se/blanketter/Documents/blankett-rapport-over-induceradeaborter.pdf 